\title{
Conflicts with Glis glis and Eliomys quercinus in households: a practical guideline for sufferers (Rodentia: Gliridae)
}

Konflikty s plchem velkým (Glis glis) a plchem zahradním (Eliomys quercinus) v domácnostech: praktický průvodce pro postižené (Rodentia: Gliridae)

\section{Sven BÜCHNER ${ }^{1}$, Roger TROUT² \& Peter ADAMÍK ${ }^{3,4}$}

${ }^{1}$ Consultancy for Nature Conservation, Ortsstraße 174, DE-02829 Markersdorf, Germany; muscardinus@gmx.net

${ }^{2}$ RABBITWISE-PLUS, Holtside, Batts Corner, Dockenfield, Farnham, Surrey GU10 4EX, UK; edibledormouse@hotmail.co.uk

${ }^{3}$ Department of Zoology, Palacký University, 17. listopadu 50, CZ-771 46 Olomouc, Czech Republic; peter.adamik@upol.cz

${ }^{4}$ Regional Museum, Náměstí Republiky 5, CZ-771 73 Olomouc, Czech Republic

received on 7 June 2018

\begin{abstract}
Across Europe, the edible dormouse (Glis glis) and the garden dormouse (Eliomys quercinus) are listed as protected species. In areas where households are close to habitats where these dormice are present, they easily penetrate into the houses. While dormice are admired by the public as cute animals, conflicts are common when dormice enter houses and cause damage, mostly on the wooden construction parts, insulation or electrical installations. Another source of nuisance is that property owners are faced with damage to stored food or dormouse urine/faeces are deposited and represent a potential source of zoonoses. In addition, the nocturnal activity of dormice disturbs the sleep regime of sensitive household owners. Here we show that while in many countries the dormice have high legal protection status, apart from few local exceptions, the house owners get little practical help from the governmental agencies on how to tackle the conflicting issue of sharing their property with protected rodents. We outline reasons why dormice enter households and identify the most common ways the animals get in. We also provide some practical recommendations on how to deal with the conflicts that arise.
\end{abstract}

Key words. Glis glis, Eliomys quercinus, human-wildlife conflict, stakeholders.

\section{INTRODUCTION}

The history of people and dormice is a long story. It ranges from the use of dormice as food, medicine and pets to pest control and dormice as transmitters of diseases (see summary by Carpaneto \& Cristaldi 1994, Kyštufek \& Flajšman 2007, Trout \& Mogg 2017). The garden dormouse (Eliomys quercinus) and edible dormouse (Glis glis) are known to frequently enter the built environment. In the garden dormouse this often occurs in urban habitats, close to gardens or rocky areas, e.g. in south western Germany in cities like Mainz or Wiesbaden. In the edible dormouse this behaviour is common in forested areas where households are within

This contribution has been presented at the 10th International Dormouse Conference held at the University of Liège, Belgium, on 11-15 September 2017 
or in close proximity to woodlands. While many people certainly welcome these animals in their houses and live alongside without conflict, there are many others who perceive dormice as a threat or a source of nuisance. For many people these species are simply 'mice' and they are perceived as a pest in their home. This dichotomy in perception of the edible dormouse was common when one of us organized a national survey with a request for presence records from the public (P. ADAMík, unpubl. data).

Over many years of work on these dormice we often came into contact with householders who reported on presence of dormice in their properties (Fig. 1). Often such a contact was accompanied by a request for advice on how to prevent the animals entering the property, prevent damage or how to remove them. The problem is that in most European countries legislation protects all species of dormice under the Bern Convention. Uniquely, in the UK the edible dormouse is a non-native species (Wildlife and Countryside Act, Schedule 9), allowing them to be trapped under an Open Licence, but live animals may not be released into the wild.

Having a legally protected species in their building puts the owner in a difficult position. There are several sources of conflict: dormice take and damage stored food (including commercial fruit/nuts), leave faeces, urine and fleas, gnaw insulation materials, damage electrical installations and fibre optic cables, gnaw water pipes and plastic tanks or any wooden construction

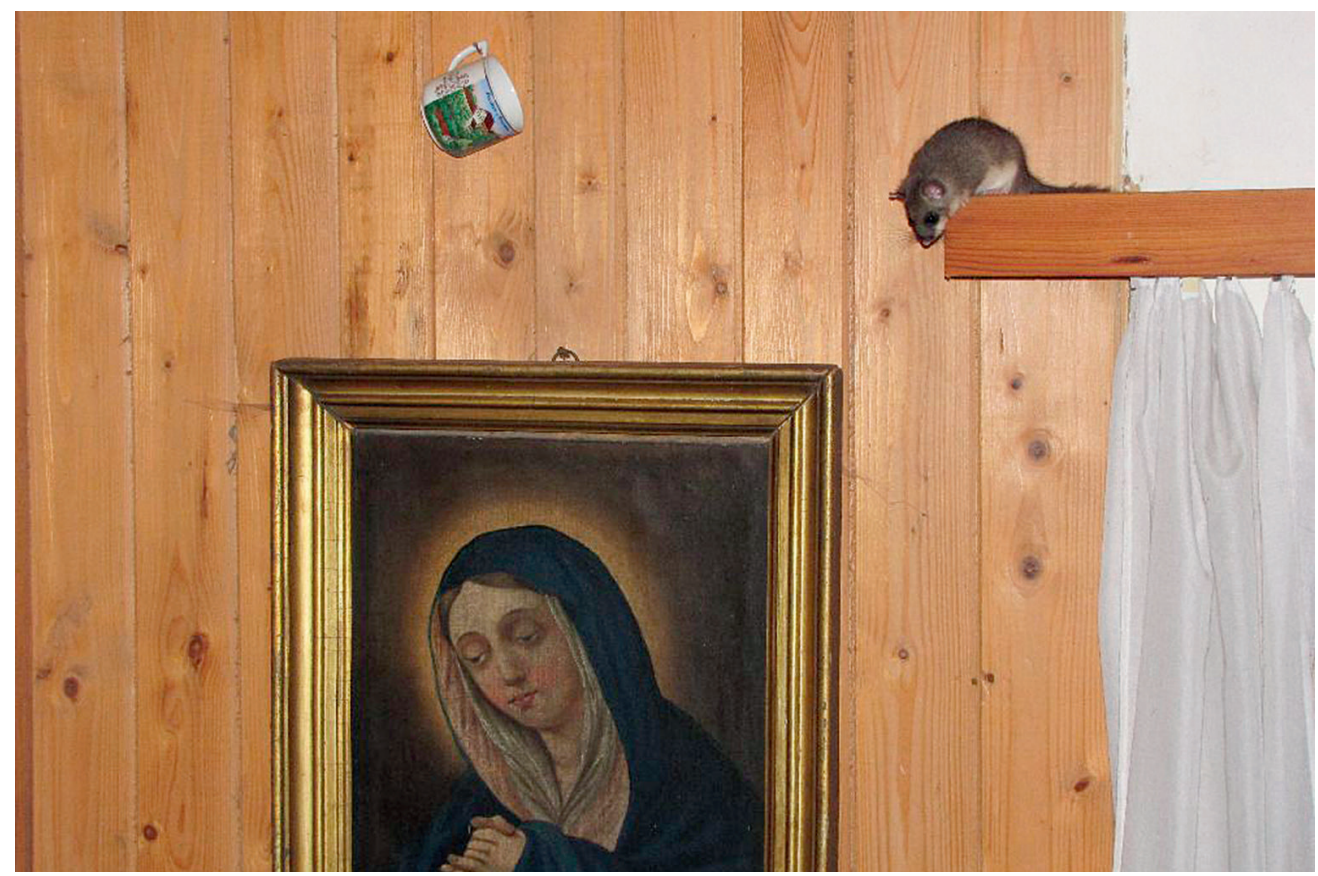

Fig. 1. An edible dormouse in a weekend house in Staré Hamry, Beskydy Mts., Czech Republic, July 2010. Photo courtesy of Jan DuFKA.

Obr. 1. Plch velký na chalupě v beskydských Starých Hamrech v červenci 2010. Foto laskavostí Jana DufKY. 


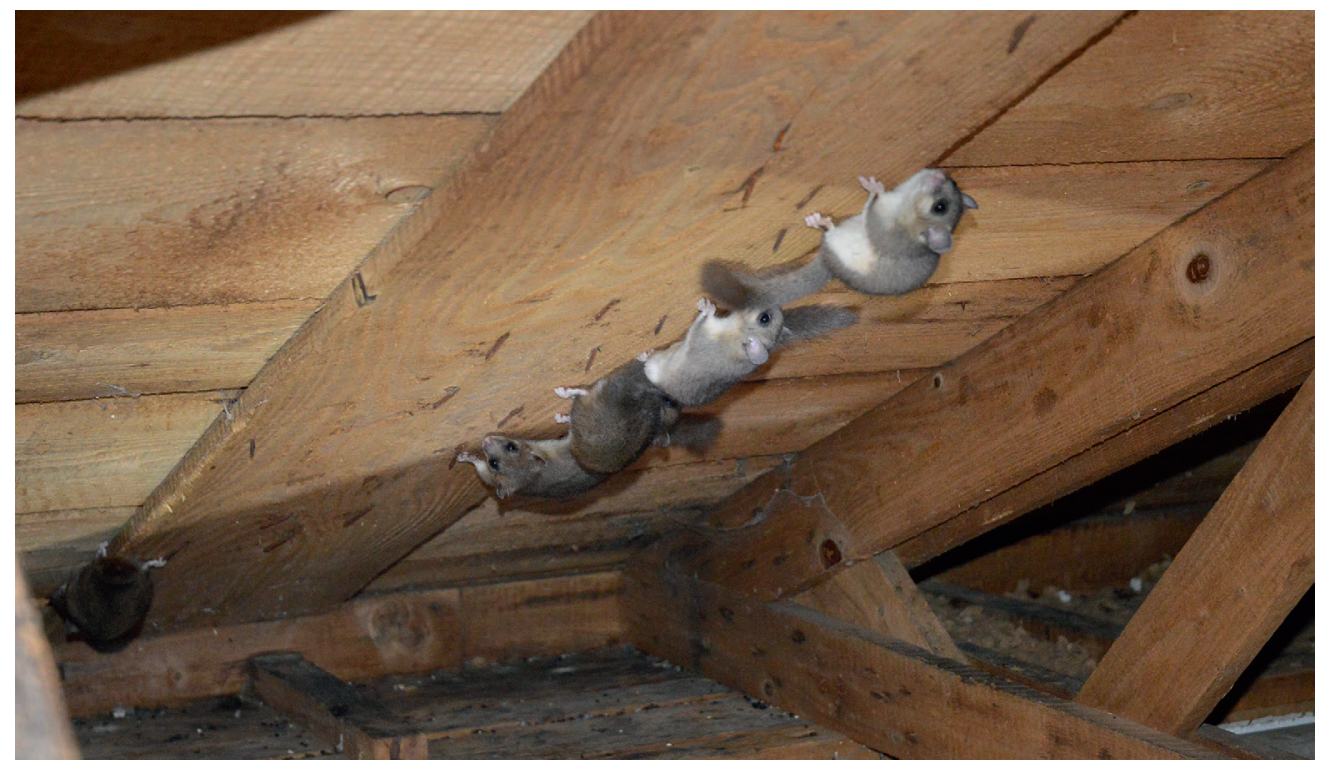

Fig. 2. Up to 11 dormice were observed in the attic of this weekend house; 20 June 2015, Malé Hradisko, Czech Republic. Photo courtesy of Ivan ČIžMÁr̆.

Obr. 2. Až 11 plchů bylo pozorováno na půdě této chalupy; 20. června 2015, Malé Hradisko. Foto laskavostí Ivana ČIŽMÁŘE.

elements. Noisy nocturnal activity can sometimes reach unbearable levels every night as the animals run over ceilings, under floors or within walls (Fig. 2). Thus, the issue resembles a typical human-wildlife conflict for members of the public that have the species in their property. Under normal circumstances one might expect that governments would provide some form of support for stakeholders. For example, in cases of human-carnivore interactions (e.g. with wolf and otter) there are compensation schemes to reimburse losses due to damage caused to livestock and fish (e.g. KLENKE et al. 2013, MontaG 2003). In the past, garden dormice in Mediterranean countries were controlled by using chlorophacinone, an anticoagulant poison (CARPANETO \& CRISTALDi 1994). This is now illegal in Europe, including England, and new ways of minimising conflict are required.

During a discussion forum the authors organized at the 10th International Dormice Conference in Liège (2017) we found that probably none of the European countries provides a compensation scheme for damage caused by dormice to properties. For most countries there appears to be no formal information or advice for property owners on how to deal with dormice as a pest. Thus, we feel there is a serious gap: on one hand governments protect the species by law and prevent stakeholders from taking any action against the animals (no handling, no disturbance allowed except under Licence). On the other hand, they do not provide information on conflict prevention or offer a compensation scheme (Table 1). Here we draw upon years of experience with house owners and present some basic recommendations on how to deal with dormice in properties. 
Table 1. Types of conflicts in different countries reported by participants at a discussion of human-dormice conflict held at the 10th International Dormice Conference 2017 in Liège, Belgium

Tab. 1. Typy konfliktů s plchy v různých zemích, sdělené účastníky diskuse v rámci 10 . Mezinárodní konference o plších konané v Lutychu, Belgie

\begin{tabular}{|c|c|c|}
\hline species / druh & country / země & type of reported conflict / typ hlášeného střetu \\
\hline \multicolumn{3}{|c|}{ edible dormouse / plch velký (Glis glis) } \\
\hline lielais susuris & Latvia / Lotyšsko & $\begin{array}{l}\text { damage of stored food in weekend houses / ničení } \\
\text { uskladněných potravin ve weekendovém domě }\end{array}$ \\
\hline popielica szara & Poland / Polsko & ditto / totéž \\
\hline didžioji miegapelè & Lithuania / Litva & ditto / totéž \\
\hline pârşul-cenusiu & Romania / Rumunsko & ditto + noise at night / totéž + noční zvuky \\
\hline обикновеният сънливец & Bulgaria / Bulharsko & ditto + noise at night / totéž + noční zvuky \\
\hline Siebenschläfer & Switzerland / Švýcary & ditto + noise at night / totéž + noční zvuky \\
\hline ghiro & Italy / Italie & $\begin{array}{l}\text { ditto }+ \text { noise at night }+ \text { damage to fruit crop } \\
/ \text { totéž }+ \text { noční zvuky }+ \text { škody na úrodě ovoce }\end{array}$ \\
\hline اشكول & $\operatorname{Iran} /$ Iran & damage to fruit crop / škody na úrodě ovoce \\
\hline loire gris & France / Francie & $\begin{array}{l}\text { food damage }+ \text { noise at night }+ \text { faeces } \\
/ \text { ničení potravin }+ \text { noční zvuky }+ \text { trus }\end{array}$ \\
\hline edible dormouse / glis & $\begin{array}{l}\text { UK / Spojené } \\
\text { království }\end{array}$ & $\begin{array}{l}\text { house damage, food damage }+ \text { noise at night } \\
+ \text { faeces }+ \text { activate alarm systems }+ \text { drown in } \\
\text { water tanks / ničení domu, ničení potravin }+ \text { noční } \\
\text { zvuky }+ \text { trus }+ \text { spouštění poplašného systemu }+ \\
\text { padání do vodní nádrže }\end{array}$ \\
\hline Siebenschläfer & Germany / Německo & $\begin{array}{l}\text { ditto + hygienic problems in stores, restaurants, } \\
\text { hospitals and retirement homes / totéž + hygienické } \\
\text { problémy ve skladech, stravovnách, nemocnicích } \\
\text { a starobincích }\end{array}$ \\
\hline plch velký & Czechia / Česko & $\begin{array}{l}\text { food damage }+ \text { noise at night }+ \text { faeces }+ \text { house } \\
\text { damage / ničení potravin }+ \text { noční zvuky }+ \text { trus }+ \\
\text { ničení domu }\end{array}$ \\
\hline \multicolumn{3}{|c|}{ garden dormouse / plch zahradní (Eliomys quercinus) } \\
\hline vrtni pohl & Slovenia / Slovinsko & $\begin{array}{l}\text { damage of stored food / ničení uskladněných } \\
\text { potravin }\end{array}$ \\
\hline liron careto & Spain / Španělsko & $\begin{array}{l}\text { holes in irrigation systems / díry v zavlažova- } \\
\text { cím systemu }\end{array}$ \\
\hline Gartenschläfer & Switzerland / Švýcary & food damage / ničení potravin \\
\hline quercino & Italy / Italie & ditto \\
\hline lerot & France / Francie & ditto \\
\hline Gartenschläfer & Germany / Německo & $\begin{array}{l}\text { ditto }+ \text { faeces }+ \text { house damage / totéž }+ \text { trus }+ \text { ničení } \\
\text { domu }\end{array}$ \\
\hline
\end{tabular}


A fundamental challenge is our poor knowledge of why these species want to enter some properties (but not others nearby). Understanding this generic issue can lead to methods for reducing the desire to enter, suggesting how we might prevent it and thus reduce conflict. There seems to be no single reason. The animals may seek a refuge for climatic reasons. They may need food or (especially) water where it is in short supply nearby but available from water storage tanks. Buildings offer refuge from intra- and interspecific competition relating to local density, including lack of natural daytime refuges nearby. We also cannot exclude the possibility that these animals are simply curious and investigate several places to rest, feed and breed. They may therefore also come into houses by chance and stay there if there is easy access and they find agreeable conditions. Dormice use scent marks to orientate and both species are social animals. Therefore, a place once chosen by these dormice could attract more individuals that follow scent trails.

The numbers of edible dormice captured in a UK housing estate of 65 properties varied considerably from year to year (perhaps due to breeding and non-breeding years) and house infestations ranged from 1 to 145 individuals removed in one season (Trout \& MogG 2017). Additionally, several repeated periods of trapping were often needed. This indicates a continuing pressure (or alternatively ongoing attractiveness) for edible dormice living nearby to enter that particular property once those inhabitants originally present had been removed. In many cases, monitored edible dormice left the building most nights to feed nearby (R. TROUT, unpubl. data).

\section{RECOMMENDATIONS}

Any direct or indirect action against dormice in houses has to consider the legal aspects as well as animal welfare. A Licence will probably be needed before any action is taken. Many of the recommendations below are based on limited experience rather than scientific experimental work and subsequent monitoring. Some will be helpful but may not work in all cases nor be permanent, especially if there is a large reservoir population nearby. Rigorous execution of planned actions is required. Some practical guidance for owners provided by Governmental organisations could help to minimize the conflicts.

\section{PREVENTION}

The first step should be to minimize the ease of access to the building. Both species are excellent climbers and can climb both up and down external walls and rainwater pipes. The edible dormouse is especially arboreal and branches of trees that even slightly overlap with the roof often function as bridges between woodland and the building. The garden dormouse seems also to use bridges from vegetation into the house. Removing wall-climbing plants, branches or trees close to the building reduces easy access. Some thinning and making the space more open (breaking arboreal links) reduces potential bridges for the animals.

Entrance holes into the house should be closed. Even small crevices of $2 \mathrm{~cm}$ in diameter can be enough for animals to enter the building. The roof is often the weakest part. Metal mesh under the tiles, especially at edges and corners, will obstruct entry. Plastic formers for valleys and ridges in modern roofs are easily bypassed or bitten through by edible dormice (R. TROUT, unpubl. data).

Holes around pipes, drains, fibre optic cables or water pipes should be sealed at the point where they enter the building, using a strong mix of cement. This includes underground places because edible dormice may hibernate in the softer earth alongside drains and cables (we know 
less about hibernacula of garden dormice). Metal mesh pushed firmly in the gaps will obstruct entry. Construction foam is very easy for these rodents to gnaw and will only be effective if metal mesh has also been inserted. It is helpful to prevent individuals accessing structures where they can then run through the whole building, for example gaps in internal partition walls adjacent to ceiling/floor spaces, cavity walls and especially false ceilings which are present in many offices, hospitals and industrial buildings. Inside the building it is very important to close any gaps around pipes where they enter the rooms (e.g. behind kitchen units or bathroom fittings). These retro-works on existing buildings should preferably be done during the winter when dormice have probably left the house. Some edible dormice hibernate under floors, but most leave houses during the winter to hibernate outside. If it can be arranged, important holes can be filled at night and branches cut back after all the dormice have left the building to find food. For new buildings in areas where problems with dormice in houses are known, blocking gaps should be very rigorous and closely monitored during construction. The same applies for refurbishment of kitchens and bathrooms or installing central heating pipes.

Inside the house, kitchen doors should be closed and food storage made inaccessible. Any potential food should be hidden away to avoid attracting dormice, remembering that they can and do enter through open windows.

One should recognise that it is sometimes impossible to block all entrances for dormice, especially into old houses situated in or very close to woodland. At some places in Germany, the number of garden dormice trying to enter the house could be reduced by putting up nest boxes in the garden (SEYBOLd 2018). It is possible that there is less pressure on houses where more attractive habitats are available outside.

Once the animals occupy a house or facility there are two options on how to get them out: deterrence and trapping. Keeping a cat could also be helpful.

\section{DETERRENCE}

Dormice use scent marks to orientate and they often follow well defined trails. Thus, they are very sensitive to smells. It could help to use strong smelling substances as repellents, or to mask an existing trail especially at places where the animals come into the house. Unfortunately, there is no type of smell that works permanently and everywhere, or for a long period. SEYBold (2018) obtained good results with vinegar essence, essential oils like peppermint or eucalyptus and indirect burning of frankincense (olibanum). Burning incense should be done on several successive occasions and creates a risk of fire. Neighbours and local fire fighters need to be informed of what is being done. Application with a puffer of a mixture of flour and black pepper intensifies repellent effects. This dust accumulates in dormouse fur and it seems to be uncomfortable for them (SEYBOLD 2018).

Deterrence should start immediately on completion of a trapping period to mask the entrance route scent trail - if the entrance hole cannot be sealed or dormice can enter along a complete length of e.g. gutterline. There is no proven effect of ultra-sonic sound or other noise emitters on dormice.

\section{TRAPPING}

As a last resort, where prevention of entry and deterrence has failed, live trapping of dormice could reduce the problem. Trapping of dormice requires experience and, in most countries, a special licence. In England all edible dormice captured must be killed and not released and 
only specified traps are legal for killing, restricted by the Spring Traps Approval Order (Fig. 3). Elsewhere it has to be clear where to translocate the animals.

There is no point releasing dormice in the nearby forest because individuals can be expected to soon return. Edible dormice may travel in one night more than $600 \mathrm{~m}$ in their home range (JURCZYSZYN \& ZGRABCZYŃSKA 2007). Home range distances in the garden dormouse suggest more than $700 \mathrm{~m}$ is possible (VATERLAUs 1998). Thus, it can be assumed that both species know their landscape within a radius of about $1 \mathrm{~km}$. Animals should therefore be translocated at least $3 \mathrm{~km}$ from their trapping point. However, very little is known about adaptation to new release sites and survival rates of translocated animals. In general, we advise to release them in similar habitat as surrounded the capture site. For edible dormouse that would normally be mature forest with deciduous trees present, but not someone else's garden.

It is especially challenging to trap dormice in food stores or restaurants, so entrance blocking is more appropriate. Attractive baits for dormice smell strongly (e.g. chocolate cream, peanut butter or ripe fruits). It is recommended to use large-sized live-capture traps. An active, springpowered closing mechanism entrance can cause broken and lost tails in dormice. Sherman live traps cut off some garden dormouses tails with the fast closing entrance door (S. BüCHNER, unpubl. data). However, once the trap entrance is closed, it is preferable to have a secure locking mechanism. There are observations of garden dormice working in a team opening live traps to

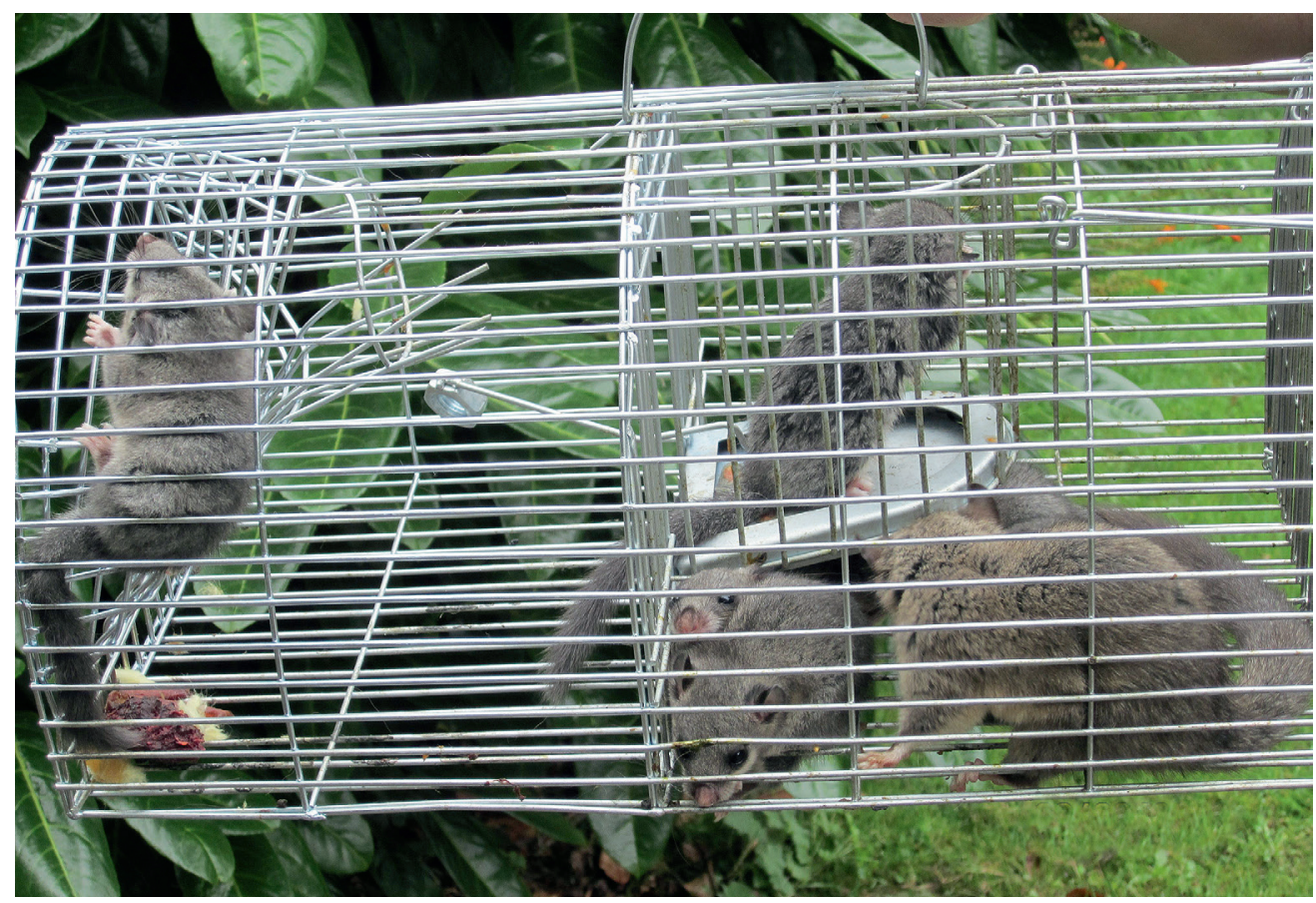

Fig 3. Successful multicapture trapping - mother and young. Photo by Roger TrouT.

Obr. 3. Úspěšný odchyt vícero jedinců - matky a mlád’at. Foto Roger TROuT. 
free their mates and to take away the bait (S. BüCHNER, unpubl. data). Trapping sessions should be conducted with many traps at once. They must be inspected at least once per 24 hours and fresh fruits should be offered daily in the trap to avoid starving dormice. In England trapping may take 2 weeks or more to adequately reduce the population in the building but may need repeating several times in one year if the entrance holes are not discovered and blocked.

\section{SOUHRN}

V celé Evropě jsou plch velký (Glis glis) a plch zahradní (Eliomys quercinus) považováni za chráněné druhy. Oba však v oblastech, kde se domy nacházejí v kontaktu s biotopy obývanými těmito druhy, snadno pronikají do domácností. I když jsou veřejností plši obdivováni jako roztomilá zviřátka, pokud vstupují do domů, dochází snadno ke konfliktům, nebot' dokážou způsobovat škody, většinou na dřevěných konstrukčních částech, izolacích nebo elektrických instalacích. Dalším zdrojem obtíží je skutečnost, že plši poškozují uložené potraviny anebo ukládají v domech moč a trus a jsou tak potenciálním zdrojem zoonos. Navíc noční činnost a hlasové projevy plchů narušuje režim spánku citlivých majitelů domácností. Zde ukazujeme, že zatímco v mnoha zemích mají plši silnou právní ochranu, s výjimkou několika místních výjimek majitelé domů dostávají od vládních agentur minimální praktickou pomoc či rady, jak řešit konfliktní otázku sdílení svého majetku s chráněnými hlodavci. Uvádíme důvody, proč plši vstupují do domácností a ukazujeme nejčastější zpo̊soby, jakým se do nich zvířata dostávají. Dále uvádíme praktická doporučení, jak řešit konflikty, které vznikají jejich př́itomností v domácnostech.

\section{Acknow ledgements}

We thank the participants of the discussion forum on dormice-household conflicts during the 10th International Dormice Conference in Liège, 2017 for sharing their experience. Pat MorRIs revised the first draft of this paper and we are thankful for his input.

\section{REFERENCES}

Carpaneto G. M. \& Cristaldi M., 1994: Dormice and man: a review of past and present relations. Hystrix, n. s., 6(1-2): 303-330.

JURCZYSZYN M. \& ZGRABCZYŃSKA E., 2007: Influence of population density and reproduction on space use and spatial relations in the edible dormouse. Acta Theriologica, 52: 181-188.

Klenke R. A., Ring I., Kranz A., Jepsen N., Rauschmayer F. \& Henle K. (eds.), 2013: Human-Wildlife Conflicts in Europe. Springer, Berlin, 322 pp.

Kryštufek B. \& FlajŠMan B., 2007: Polh in človek. Ekološki forum, Ljubljana, 248 pp.

Montag J., 2003: Compensation and predator conservation: Limitations of compensation. Carnivore Damage Prevention News, 6: 2-6.

SEYBOLd K., 2018: Hilfe - Kobolde im Haus! Ein Leitfaden für bilchgeplagte Hausbesitzer. Wildtierhilfe Odenwald, $7 \mathrm{pp}$.

Trout R. C. \& Mogg A., 2017: Surveys of distribution of and damage by the Edible dormouse (Glis glis) in the built environment in England. Apodemus, 14: 27-34.

Vaterlaus C., 1998: Der Gartenschläfer (Eliomys quercinus) Ökologie, Populationsstruktur, Populationsdynamik und die Verbreitung in der Schweiz. Inauguraldissertation, Basel, 217 pp. 